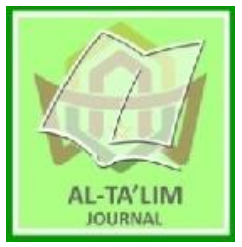

AL-TA'LIM JOURNAL, 27 (2), 2020, (215-226)

(Print ISSN 1410-7546 Online ISSN 2355-7893)

Available online at http://journal.tarbiyahiainib.ac.id/index.php/attalim

\title{
Children's Worth School: Psychological Well-Being of High School Students in State of City of Padang
}

Received: $12^{\text {th }}$ April 2020; Revised: $31^{\text {th }}$ May 2020; Accepted: $30^{\text {th }}$ July 2020

Permalink/DOI: http://dx.doi.org/10.15548/jt.v27i2.632

\section{Afnibar*)}

Universitas Islam Negeri Imam Bonjol

Padang, Indonesia

E-mail: afnibarkons@uinib.ac.id

\section{Amalia}

Universitas Malaysia Serawak, Malaysia

E-mail: mamalia@unimas.my

\section{Dyla Fajhriani. N}

Universitas Islam Negeri Imam Bonjol

Padang, Indonesia

E-mail: dyla.fajhrianinasrul@gmail.com

\section{Aulia Rahmi \\ Universitas Islam Negeri Imam Bonjol \\ Padang, Indonesia \\ E-mail: aulia.rahmi0101@gmail.com}

\section{*) Corresponding Author}

\begin{abstract}
This study aimed to reveal the condition of a child-friendly school as seen from the psychological well-being students in school. Lately there have been various harassment incidents that have befallen students and their own culprit; this is allegedly related to their discomfort at school. Interviews and observations were employed in this study. The participants which were the public high school students were recruited and determined by snowball sampling. The results showed that, generally, students experienced problems; first, psychological well-being was disrupted due to the following reasons: (1) learning environment which included incomplete classroom and extracurricular activities facilities; (2) teachers' attribute which included attitudes toward students, show less affection, appreciation and sometimes like to force the will; and (3) inadequate teaching and learning aspects which included poor lesson plans and dense of teaching and learning material. Second, psychological well-being felt by students generally in schools is related to: (1) the atmosphere in the classroom: friendly and not grumpy teachers, fun teachers in explaining the lesson; (2) understanding and easygoing friends who are comfortable to communicate with, and (3) the atmosphere outside the classroom, friendly waiters in the canteen and a comfortable and quiet library.
\end{abstract}

Keywords: School; psychological well-being; harassment; students.

How to Cite: Afnibar, A., Amalia, A., Nasrul, D., \& Rahmi, A. (2020). Children's worth School: Psychological Well-Being of High School Students in Padang. Al-Ta lim Journal, 27(2). doi:https://doi.org/10.15548/jt.v27i2.632.

\section{INTRODUCTION}

Schools as one of the formal educational institutions, carry out the task of realizing educational goals, namely helping students actively develop their potential to gain spiritual strength, religion, self-control, personality, intelligence, noble character and the skills needed by themselves, society, nation and countries (Alif et al., 2020; Gomezelj Omerzel \& Trunk Širca, 2007; Guglielmino, 2013).
Development of optimal self potential requires a comfortable atmosphere, which is a school that is able to provide the best experience for students, which is filled with feelings of calm, calm, and happy.

A good school is a school that is expected to be able to provide the best experience for students so as to make their students feel physically and psycho-logically well-being because the welfare of students 
affects almost all aspects for optimizing the function of students in school (Burgess \& Briggs, 2010; Johnson et al., 2000; White \& Waters, 2015).

In this globalization era, education in schools is very important for individuals, especially students because of the right time to form a good person and hone creativity. Education is made so that students have special abilities in their respective fields. One of formal education is the Islamic boarding school which is now extending its existence in Indonesia. Secondary school education is part of the national education system that helps educate the nation and succeed national development. Students will get a lot of experience, both pleasant and unpleasant experiences.

Students especially young people develop very closely related to the environment (Feldman et al., 2009). The social environment that influences students is the school which is an important element in the process of individual development because it functions as a career choice in the future and is a means of learning about knowledge about social roles and norm boundaries (Casper, 2001; McNeill et al., 2006; Ryan \& Patrick, 2001).

In line with the concept of the Organization for Economic Co-operation and Development (OECD) which was used as a reference by the Indonesian Ministry of National Education in evaluating the implementation of the functions and roles of schools in Indonesia which have recommended qualitative parameters in evaluations such as in England and Wales, namely in the form of spiritual, moral aspects, socio cultural, and school contributions in the development of well being of students. Well-being is also often interpreted by researchers as prosperous (Prawitasari, 2011). Feeling calm and serene is a desire that exists in each individual person. Psychologically well-being is one of the things that give a feeling of happiness and satisfaction in living a life in a student at school. Well- being consists of life satisfaction and positive feelings such as feeling happy, happy and satisfied. Someone who wants to have a good quality of life ideally also has psychological well-being or is known as psychological wellbeing, which is also good in him. Jayawickreme et al. (2012) also suggests that welfare is building happiness that is important. Welfare theory defines that positive psychology material is the real thing but on the contrary it is a thing that builds the welfare of the individual.

The theory of psychological well being was coined by Ryff in 1989. Psycho-logical well being is the ability of individuals to regulate their emotions wisely, able to develop warmth or dynamic relationship with others, have the independence in the face of the social environment, control the external environment, set goals in life, and realize his potential continuously. These capabilities had pursued by focusing on self-realization, self-expression and actualization of her potential positive so it can function fully and achieve happiness (Faizah et al., 2020; Prabowo, 2016).

Psychological well being is based on a persons' feelings about his life activities that take place every day in which the process experiences fluctuations in thoughts and feelings that start from negative mental states to positive mental conditions such as trauma to the acceptance of life. Psychological well being originated from the belief that prosperity which is positive not only their physical illnesses. Psychological well being consists of the need to feel psychologically (psychological well being) (Brown \& Ryan, 2003; Deci \& Ryan, 2008; Huppert, 2009; Ryff \& Singer, 2008; Scheier et al., 2001; Wright \& Cropanzano, 2000). The description of the characteristics of people having psychological well-being refers to Rogers' view of a fully functioning person and Maslow's view of self actualization, Jung's view of in valuation, Alport's concept of maturity, according to Erikson's concept in describes individuals who achieve integration 
rather than despair and Negatron concepts about life satisfaction, as well as positive criteria about healthy-minded people put forward by Johada.

Feelings of psychological well-being are important for all people, so that they can be active in their daily lives effectively. Likewise, students, when they are at school, are expected to have psychological well-being. Psychological well being leads to the feelings of individuals (students) undergoing daily living activities. All activities carried out by individuals that take place every day in which the process experiences fluctuations (changes) of thoughts and feelings that start from negative mental states to positive mental states, psychological well-being or psychological well being is a term that can be used to describe the psychological health of individuals in accordance with the fulfillment of positive psychology function criteria (Sianturi et al., 2019).

The happiness and satisfaction of life felt by a student at school becomes an important element in seeing how high psychological well-being they experience in undergoing learning and learning activities. Psychological well-being can help participants to grow positive emotions, feel life satisfaction and happiness, reduce depression, and negative student behavior. Psychological well-being is needed by students in school so that they can undergo learning and learning activities effectively and efficiently while disturbed Psychological well-being can cause students to be lazy, lethargic and not excited, even unable to concentrate. Various problems faced by students in schools are the result of lack of psychological well-being.

Supported by Erford's (2007) opinion which cites various research results, between 3 and 6 million students experience clinical depression; more than $50 \%$ of all students experience mental depression which can be diagnosed through wrong behavior, wrong treatment, excessive attention or lack of attention, more than $50 \%$ of students receive emotionally abusive treatment which can cause they dropped out and almost 5 million students received special education services. This has led to the emergence of natural schools, or home schooling, which have begun to grow and flourish lately (Lee, 2005; Sink \& Stroh, 2003). Supported by observations in the field the role of schools seems to be suboptimal when viewed from the level of juvenile delinquency in Indonesia. The problem of juvenile delinquency in Indonesia is increasingly alarming and incarnates into a critical social problem because it has led to various forms of crime.

The same research in Indonesia, problems that occur in students, such as: like to skip class, often late, there is reluctance of students to come to school, and they are happy if they do not learn because the teacher has a meeting or other activities. There are even students who say goodbye to school asking their parents to pray so that later the teacher does not get angry and everything is fine. This fact is a sign of the unhappiness of students in schools that can disrupt the realization of optimal development. Psychological well-being refers to optimal psychological experiences and functions which include the functions of selfautonomy, environmental mastery, personal growth, positive relationships with others, life goals and acceptance. Even students feel less happy and less satisfied with their lives. Actually students are able to feel the ongoing learning process related to the convenience of learning, meaningful learning, and enjoyable learning (Arnold et al., 2007; Wardle \& Cooke, 2005).

Psychological well-being conception refers to the cognitive and affective evaluation of a person towards the lives of students. Learners want psychological wellbeing, such as a positive emotional state caused by a match between student personal needs and expectations of the school. Students want psychological well-being as attitudes, moods, health, resilience, calm life and student satisfaction with themselves 
and relationships with others. The process of fulfilling the task of adolescent development does not always run smoothly because it faces pressure and obstacles due to physical, cognitive, social, and emotional vulnerability. The condition of adolescents especially students of this kind can influence adolescents in considering the suitability of their ideals, abilities, interests, talents, emotional conditions, and future thinking (Santrock, 2002). One of the attractive conditions to be discussed is the Psychological well being of participants students in city high schools Padang. The aim of the study to explore the child-friendly school from psychological well-being among public high school students. Hence, the main research question was What are issues/challenges/problems to enhance students' psychological well-being?

\section{METHOD}

The research method used is qualitative research, namely research that uses a naturalistic approach to search for and find understanding or understanding of phenomena in a particular contextual setting (Moleong, 2011). Based on the focus and objectives of the research to be achieved in this study, the research design used is descriptive. Descriptive research is research that describes facts or circumstances accurately and actually happens when this research is conducted. The understanding of descriptive research is a research method that aims at describing the phenomena that exist and are taking place now and in the past. Research does not hold manipulation or alteration of the variable conversion free, but it describes the data in detailed.

Samples in qualitative research are not called respondents, but as resource persons or participants, informants, friends and research groups. In fact, it can use the term research subject. The subjects of this study were the state secondary students of Padang City, which were determined by snowball sampling. Mechanical snowball sampling is a method for identifying chose and takes samples in a network or straight chain relationships. Through this technique in this study obtained 20 students of Padang City public secondary schools. Data collection techniques with in-depth interview techniques, by combining inductive interview techniques. To get a complete understanding because qualitative research results emphasize more meaning than generalization (Afifuddin \& Saebani, 2012).

The data validity test technique is done by; credibility, transferability, dependability, and conformability. How to research empirical problems by following a series of procedures that have been specified previously. Data analysis was carried out by following the data reduction, data presentation, and conclusion drawing (Hashimov, 2015; Huberman \& Miles, 2002). The analysis technique is carried out in stages, following describing what the interview results are, grouping them according to the purpose of the study, interpreting, and drawing conclusions. Method Section that describes the participants, the procedures employed in the study such as technique of data collection and data analysis.

\section{RESULT AND DISCUSSION}

Psychological well being is disturbed by many students in school. The research findings show that all respondents stated that school work is too much, and "teacher performance is less able to manage classrooms, and make learning boredom, and go home from school for too long. For that we need the role of well being interventions carried out in schools, because it can improve self-regulation and decrease anxiety and stress levels of students (Ruini et al., 2009; Tomba et al., 2010). ST (2011) learners like teacher humorous, humorous attitude of the teacher made the students feel more relaxed and comfortable in the following study. 
The same statement was stated by Iriantara (2014) that in any communication practice, including learning communication, humor is an important ingredient in the communication process. Relationships among participants in the communication process become more fluid because of humor. Humorous teacher in the field can prevent many expressions of learners school secondary who argued that the disposition of teachers who are not comfortable (killer / grumpy and rigid / less humorous) and bore make learners feel bored in class. This type of teacher makes students feel uncomfortable and depressed so that students feel boredom and boredom. The following inconvenience, which is felt by most students are friends who are nosy and create annoyance to other friend. Students who are subjected to bullying usually become victims of bullying. There are many cases in schools found by researchers that make students feel uncomfortable being in school.

Supported based on interviews in the field some students stated that "learning facilities are incomplete, classes that are less comfortable make students feel uncomfortable in learning". The learning space as a place of interaction between teachers and students needs to be designed in such a way that it does not merely fulfill functions, but is able to provide protection, comfort, security and a sense of pleasure for its inhabitants (Sativa, 2010). The inconvenience in joking also requires various efforts to create a learning atmosphere that is comfortable, fun and meaningful for students at school. Student learning comfort can be realized with a clean class; good class lighting; comfortable room temperature (around $25^{\circ}$ $28^{\circ} \mathrm{C}$ ); Seating arrangement and ergonomics; the use of instrumental music; low class noise level; class order; and structuring the learning community (students-teacher-parents) that supports the learning process.

In addition, the interview that the author did to learners medium Padang city, the argue that the task at school too much make learners feel bored and tired of learning. In line with the opinion of Syah (2012) that the boredom of learning can hit a student if he has lost motivation and loses the consolidation of one particular skill level. In addition, boredom can occur because the learning process of students has reached the limits of physical ability because of boredom and fatigue. Observations made in several classes show that in general students find it difficult to concentrate; there are those who are busy chatting, doing their own activities, and often leaving and entering the classroom again. In addition to the various conditions that illustrate the disfavor of students at school, from the interviews it is known that there are things that make them feel psychological wellbeing, namely: "When learning with a teacher who is fun means friendly, and not grumpy, so do not be sleepy learning with him ". School as the second environment that students enter beside the family, occupies an important position in preparing them for the future. Various difficulties experienced by students at school can affect learning achievement at school, among the sources of the difficulties are: too many school assignments teachers do not clearly explain the subject matter and monotonous learning. These reasons make students indicated psychologically stressed, and indicate that students have low welfare. The above research findings can be described sequentially in the comparison table as follows:

Table 1: Comparison Well and Disturbed Being

\begin{tabular}{lll}
\hline No & $\begin{array}{c}\text { Well-being disturbed } \\
\text { at school }\end{array}$ & \multicolumn{1}{c}{$\begin{array}{c}\text { Well-being } \\
\text { conditions at school }\end{array}$} \\
\hline 1 & $\begin{array}{l}\text { School work is too } \\
\text { much }\end{array}$ & $\begin{array}{l}\text { Easy task and not } \\
\text { much }\end{array}$ \\
2 & $\begin{array}{l}\text { Performance teachers } \\
\text { who are less able to } \\
\text { manage a classroom } \\
\text { and make learning } \\
\text { boredom. }\end{array}$ & $\begin{array}{l}\text { means frudying with a } \\
\text { not bad tempered }\end{array}$ \\
3 & $\begin{array}{l}\text { Friends who are nosy } \\
\text { and make annoyances } \\
\text { with other friends. }\end{array}$ & Friend park fun for \\
&
\end{tabular}




\begin{tabular}{|c|c|c|}
\hline No & $\begin{array}{c}\text { Well-being disturbed } \\
\text { at school }\end{array}$ & $\begin{array}{c}\text { Well-being } \\
\text { conditions at school }\end{array}$ \\
\hline 4 & $\begin{array}{l}\text { Home from school for } \\
\text { too long }\end{array}$ & $\begin{array}{l}\text { When you get home } \\
\text { early }\end{array}$ \\
\hline 5 & $\begin{array}{l}\text { Less complete } \\
\text { learning facilities, less } \\
\text { comfortable classes } \\
\text { make students feel } \\
\text { uncomfortable in } \\
\text { learning }\end{array}$ & $\begin{array}{l}\text { Doing work together } \\
\text { outside the classroom }\end{array}$ \\
\hline 6 & $\begin{array}{l}\text { The teacher's } \\
\text { discomfort (grumpy } \\
\text { and stiff / less } \\
\text { humorous) and boring } \\
\text { make students feel } \\
\text { bored in the class }\end{array}$ & $\begin{array}{l}\text { Teachers who can } \\
\text { share as friends }\end{array}$ \\
\hline
\end{tabular}

So, Psychological well-being not only refers to negative mental health, but also refers to how students are able to develop their potential and abilities optimally, as individuals who function both physically, emotionally and psychologically. Psychological well-being as an achievement of the psychological potential of students and a situation where students can accept their strengths and weaknesses, develop good relationships with others, be able to control the environment, become an independent person, have a purpose in life and continue to develop personally. Psychological well-being is a term used to describe the psychological health of students. Psychological well-being plays an important role for all students in carrying out daily activities in life because psychological well-being refers to a person's feelings about his life activities. Individuals who are able to accurately measure their strength in completing tasks or problems make it easier to feel prosperous. Conversely, individuals who are not able to accurately measure their strengths are not easy to feel prosperous (Pramudita \& Pratisti, 2015).

Factors that can affect a person psychological well-being according to Ryff include: 1) Demographic factors, which affect psychological well-being, namely age, gender, socioeconomic status, and culture. 2) Social support, is defined as a sense of comfort, attention, appreciation, or help that is perceived by an individual that is obtained by various sources, including spouses, families, friends, coworkers, doctors, and social organizations. 3) Evaluation of life experiences, covering various fields of life in various periods of life. Individual evaluation of his life experience has an important influence on psychological well-being. 4) Locus of Control (LOC), is defined as a measure of a person's general expectations regarding reinforcement (reinforcement) that follows certain behaviors, can provide predictions of psychological well being (Ramadhani et al., 2016).

Based on the above findings about the comfort and inconvenience experienced by students at school, it can be seen its relationship with the dimensions that influence the psychological well-being, that dimension can be grouped into two aspects, namely: personal aspects and social aspects:

\section{Personal Aspects}

\section{Dimension of Self-Acceptance}

The ability to accept themselves in terms of both positive and negative. Someone who evaluates themselves positively is an individual who understands and accepts various aspects of himself, including good and bad qualities, can actualize themselves, function optimally and be positive towards the life he lives.

This dimension is the main characteristic of mental health and also as a main characteristic in self-actualization, optimal functioning and maturity. Good self-acceptance is marked by the ability to accept them as they are. This ability enables a person to be positive about oneself and the life he leads. This is according to indicate a person has a high psychological well-being. Indicators of self acceptance include positive evaluation, the ability to acknowledge some aspects of self, and the ability to accept both positive and negative self qualities. 


\section{Dimensions of Autonomy}

The dimension of autonomy concerns the ability to self determination, is free and has the ability to regulate one's own behavior. Being able to be independent and able to resist social pressure to think and act in certain ways and without the intervention of others. Individuals who are low in the dimension of autonomy will pay close attention and consider the expectations and evaluations of others, hold on to the judgment of others to make important decisions, and are easily influenced by social pressure to think and behave in certain ways. People can function fully by having a self-evaluation, where a person does not look at others to get an evaluation, but evaluates oneself with a standard of him without dependence on others.

\section{Dimension Life Purpose}

Individual who have good life goals are characterized by having life and awareness of anger, feeling meaningfulness in their present and past lives, holding beliefs and giving purpose in life, and having a long-term purpose in life? A person who is high in this dimension is an individual who has a direction and purpose in life that clearly feels meaning in living today and has lived it, has a belief that gives life goals and has clear goals and goals in life.

Conversely someone who has a low purpose in life will lose the meaning of life, direction and ideals that are not clear, do not see the meaning contained for his life from events in the past, and do not have meaningful hopes or beliefs in life.

\section{Social Aspects}

\section{Dimensions of Positive Relationships with Others}

The ability of individuals to establish good relationships with others around them. Individuals who are tall in this dimension are characterized by being able to foster a warm and trusting relationship from others. In addition, the individual also has a concern for the welfare of others, can show empathy, affection, and understand the principle of giving and receiving in interpersonal relationships. Conversely, individuals who are low in the dimension of positive relationships with others, isolated and frustrated in fostering interpersonal relationships, do not wish to compromise in maintaining relationships with others. Many theories emphasize the importance of warm interpersonal relationships and mutual trust with others. A positive relationship with others is when individuals are able to feel warmth and have a sense of trust in other individuals.

\section{Dimensions of Environmental Mastery}

Someone who has a good mastery of the environment is characterized by having a feeling of mastery and being able to manage the environment, has the ability to control the social environment, use opportunities in the social environment effectively, and be able to choose and create contexts according to their physical state and personal values.

Conversely someone who has a low mastery of the environment is characterized by difficulty managing daily affairs, feels unable to change or improve the relationships around him, is not aware of the opportunities around him, lack of mastery over the outside world.

Development theory describes
environmental control as the ability to
manipulate and control complex
environments. A healthy mentality is
characterized by the ability of individuals to
have or create an environment that is in
accordance with their physical conditions, able
and competent to regulate the environment,
arrange complex controls over external
activities, use effectively opportunities in the
environment, and be able to choose and create
contexts that suit their needs and individual
value it.

Development theory describes environmental control as the ability to manipulate and control complex environments. A healthy mentality is characterized by the ability of individuals to have or create an environment that is in accordance with their physical conditions, able and competent to regulate the environment, arrange complex controls over external activities, use effectively opportunities in the environment, and be able to choose and create value it. 


\section{Dimension Personal Growth}

One must develop one's own potential to grow and develop into humans. The need to self-actualize and realize one's potential is central to a clinical perspective on personal growth. This may also be closest to Aristotle's idea of eudemonic, namely how individuals can live in their true selves and actualize themselves. Have the desire to continue to develop their potential, grow as individuals who can function fully. Individuals who can function fully are individuals who can be open to experience so that they will be more aware of their surroundings.

Someone who has low personal growth will feel himself experiencing stagnation, not seeing improvement and self-development, feeling bored in losing interest in his life, and feeling unable to develop good attitudes and behavior. So, the six dimensions are broken down into: personal aspects, namely selfacceptance, autonomy, and life goals. Outside social aspects, namely: harmonious relationships with others, environmental mastery and personal growth, become the basis in determining psychological well-being. This study focuses on the disrupted and undisturbed psychological well-being experienced by students in school.

In addition, students learning comfort can be realized by clean classrooms, good classroom lighting, comfortable room temperatures (around $25^{\circ}-28^{\circ} \mathrm{C}$ ); seating arrangement and ergonomics, the use of instrumental music, low class noise levels, classroom discipline, and structuring of the learning community (student-teacher-parent) that supports the learning process. This statement also supported by the opinion of Suleman \& Hussain (2014) states that the comfort of the learning atmosphere one of which depends on the level of classroom hygiene. Clean environment is very influential at a concentration level of learning of students. Students who study in a clean environment feel more comfortable and concentrate in learning because they are not disturbed by dirty objects and odors.

Rains \& Keating (2011) also argues that the adequacy of lighting in a room can affect the comfort level of class-mates. Even the adequacy of lighting in the space also has an impact on the sustainability of activities in the space. Space classroom with little lighting makes the room becomes dark or dim, as a result the classroom looks so gloomy. On the other hand, too much lighting will glare and make the students' eyes experience uneasy. This is in accordance with the lighting in the classroom. Classroom lighting plays an important role in the learning process. Classrooms with good lighting will be able to help students in activities in learning. A good lighting design must be intended not only for the need for visual appearance, but also for other needs for learners for light and some of the biological needs of students for light including the need to focus on activities and needs for a pleasant space especially for participants students in learning activities.

In addition, windows can be provided in the classroom with natural lighting, views, ventilation and communication with the outside world. They can affect thermal discomfort, glare, and noise. So in determining the direction of the opening it is necessary to pay attention to the size, position and detail of the window (Greenfield et al., 2009)

Furthermore, the room lighting standard refers to SNI no. 03-23961991: about the procedures for designing day lighting for homes and buildings. With regard to the stability of room temperature, it is in accordance with the study of air comfort (temperature and humidity) compiled by ASHRE (American Society of Heating Refrigeration and Air-conditioning Engineers) Standard 55-1992 and ISO 7730 which states that comfort temperature is a feeling in mind humans who express satisfaction with their thermal environment (Tao et al., 2018). It shows that room temperature in class is an important role in determining one comfort. Tao

(2018) 
14) also mentioned that an increase in temperature in the room can result in (1) fatigue followed by a loss of mental and physical work efficiency increasing; (2) heart rate increases; (3) blood pressure increases; (4) decreased digestive activity; (5) core body temperature increases; (6) blood flow to the skin also increases; and (7) sweat production increases.

The research results of researchers from Salford University state that natural light, temperature, air quality and individual classroom design are very important and there are three main factors for good class design, namely individualization, stimulation, and natural situations. The things that affect the comfort of students are the most significant, because air quality, light and temperature play an important role. These three things contribute to half of the total impact on students. More specifically with regard to the temperature corresponding to the equatorial climate. So, it can be concluded that the class facilities such as class cleanliness, lighting and air temperature in the class greatly affect the psychological wellbeing students.

\section{CONCLUSIONS RECOMMENDATIONS}

AND

The results showed that in general students experienced the first psychological well-being which was disturbed, with the following reasons. First is learning facilities that include classes with makeshift facilities, facilities for extracurricular activities were not complete. Second are teacher's aspects, including: teacher attitudes toward students who show less affection, appreciation and sometimes like to force the will. Third is material aspects, which includes lessons that are poorly understood, and dense material. Psychological well-being of students in general in schools is related to the atmosphere in the classroom: friendly and not grumpy teachers, teachers who are absorbed in explaining the lesson, friends who are understanding and comfortable to communicate, and atmosphere outside the classroom, friendly waiters in the canteen and a comfortable and quiet library. In general it can be said that the average public secondary school in the city of Padang is not suitable for children.

The results of this study found the real related to psychological well-being of students in schools, for several things that can be suggested to various parties. For researchers, it is necessary to conduct further research that focuses on revealing the condition of psychological well being students, along with the factors that influence it and improving the quality of the implementation and educational outcomes. Counseling teachers are expected to design and implement guidance and counseling services for students who can meet high psychological well-being. School principals should consider psychological well-being for all school personnel (students, educators and educational staff) in making various policies in the institution they lead, so that schools can be suitable for everyone. For researchers, the conditions described above in relation to a public high school and have not studied the condition of psychological well being in private schools.

\section{REFERENCES}

Afifuddin, B. A. S., \& Saebani, B. A. (2012). Metodologi Penelitian Kualitatif, Bandung, Cv. Pustaka Setia.

Alif, S., Irwan, A., \& Elihami, E. (2020). Forming Characters Of Early Children In Non-Formal Education Units. Jurnal Edukasi Nonformal, 1(1), 88-94.

Arnold, K. A., Turner, N., Barling, J., Kelloway, E. K., \& McKee, M. C. (2007). Transformational leadership and psychological well-being: The mediating role of meaningful work. Journal of Occupational Health Psychology, 12(3), 193.

Brown, K. W., \& Ryan, R. M. (2003). The benefits of being present: Mindfulness 
and its role in psychological well-being. Journal of Personality and Social Psychology, 84(4), 822.

Burgess, S., \& Briggs, A. (2010). School assignment, school choice and social mobility. Economics of Education Review, 29(4), 639-649.

Casper, M. (2001). A definition of "social environment." American Journal of Public Health, 91(3), 465-470.

Deci, E. L., \& Ryan, R. M. (2008). Facilitating optimal motivation and psychological well-being across life's domains. Canadian Psychology/Psychologie Canadienne, 49(1), 14.

Erford, B. T., \& Erford, B. T. (2007). Transforming the school counseling profession. Pearson Merrill/Prentice Hall Columbus, GA.

Faizah, F., Rahma, U., Dara, Y. P., \& Gunawan, C. L. (2020). School WellBeing Siswa Sekolah Dasar dan Siswa Sekolah Menengah Pertama Pengguna Sistem Full-Day School di Indonesia. Jurnal Kajian Bimbingan Dan Konseling, 5(1), 34-41.

Feldman, P. O., Papalia, D. E., \& Olds, S. (2009). Human development. Jakarta: Salemba Humanika.

Gomezelj Omerzel, D., \& Trunk Širca, N. (2007). The motivation of educational institutions for validation of non-formal and informal learning [PhD Thesis]. Univerza na Primorskem, Fakulteta za management.

Greenfield, E. A., Vaillant, G. E., \& Marks, N. F. (2009). Do formal religious participation and spiritual perceptions have independent linkages with diverse dimensions of psychological wellbeing? Journal of Health and Social Behavior, 50(2), 196-212.
Guglielmino, L. M. (2013). The case for promoting self-directed learning in formal educational institutions. $S A$ EDUC, 10(2).

Hashimov, E. (2015). Qualitative Data Analysis: A Methods Sourcebook and The Coding Manual for Qualitative Researchers: Matthew B. Miles, A. Michael Huberman, and Johnny Saldaña. Thousand Oaks, CA: SAGE, 2014. 381 pp. Johnny Saldaña. Thousand Oaks, CA: SAGE, 2013. 303 pp. Taylor \& Francis.

Huberman, M., \& Miles, M. B. (2002). The qualitative researcher's companion. Sage.

Huppert, F. A. (2009). Psychological wellbeing: Evidence regarding its causes and consequences. Applied Psychology: Health and Well-Being, 1(2), 137-164.

Iriantara, Y. (2014). Komunikasi Pembelajaran; Interaksi Komunikatif dan Edukatif di dalam Kelas. Bandung: Simbiosa Rekatama Media.

Jayawickreme, E., Forgeard, M. J., \& Seligman, M. E. (2012). The engine of well-being. Review of General Psychology, 16(4), 327-342.

Johnson, J. P., Livingston, M., Schwartz, R. A., \& Slate, J. R. (2000). What makes a good elementary school? A critical examination. The Journal of Educational Research, 93(6), 339-348.

Lee, C. C. (2005). Urban school counseling: Context, characteristics, and competencies. Professional School Counseling, 184-188.

McNeill, L. H., Kreuter, M. W., \& Subramanian, S. V. (2006). Social environment and physical activity: A review of concepts and evidence. Social Science \& Medicine, 63(4), 1011-1022. 
Moleong, L. J. (2011). Metodologi Penelitian Kualitatif, cetakan XXIX. Bandung: PT. Remaja, Rosdakarya.

Prabowo, A. (2016). Kesejahteraan psikologis remaja di sekolah. Jurnal Ilmiah Psikologi Terapan, 4(2), 246-260.

Pramudita, R., \& Pratisti, W. D. (2015). Hubungan antara self-efficacy dengan subjective well-being pada siswa sma negeri 1 belitang. Psychology Forum UMM, ISBN: 978-979-796-324, 8.

Prawitasari, J. E. (2011). Faktor-Faktor Pendukung Kesejahteraan Subjektif Pekerja [PhD Thesis]. [Yogyakarta]: Universitas Gadjah Mada.

Rains, S. A., \& Keating, D. M. (2011). The social dimension of blogging about health: Health blogging, social support, and well-being. Communication Monographs, 78(4), 511-534.

Ruini, C., Ottolini, F., Tomba, E., Belaise, C., Albieri, E., Visani, D., Offidani, E., Caffo, E., \& Fava, G. A. (2009). School intervention for promoting psychological well-being in adolescence. Journal of Behavior Therapy and Experimental Psychiatry, 40(4), 522-532.

Ryan, A. M., \& Patrick, H. (2001). The classroom social environment and changes in adolescents' motivation and engagement during middle school. American Educational Research Journal, 38(2), 437-460.

Ryff, C. D., \& Singer, B. H. (2008). Know thyself and become what you are: A eudaimonic approach to psychological well-being. Journal of Happiness Studies, 9(1), 13-39.

Santrock, J. W. (2002). Life-span development.

Sativa, S. (2010). Kajian Terhadap Ruang Pembelajaran di SMK Jurusan
Bangunan di Daerah Istimewa YogyakartA. INformasi Dan Ekspose Hasil Riset Teknik SIpil Dan Arsitektur, 6(1).

Scheier, M. F., Carver, C. S., \& Bridges, M. W. (2001). Optimism, pessimism, and psychological well-being.

Sianturi, N. S., Milfayetty, S., \& Lubis, M. R. (2019). Hubungan Psychology Well Being dengan Employee Engagement Ditinjau dari Masa Kerja. Proceeding ICOPOID 2019 The 2nd International Conference on Politic of Islamic Development, 1(1), 125-135.

Sink, C. A., \& Stroh, H. R. (2003). Raising achievement test scores of early elementary school students through comprehensive school counseling programs. Professional School Counseling, 6(5), 350-364.

ST, D. (2011). Strategi Pembelajaran Menyenangkan Dengan Humor. Jakarta: PT Bumi Aksara.

Suleman, Q., \& Hussain, I. (2014). Effects of classroom physical environment on the academic achievement scores of secondary school students in kohat division, Pakistan. International Journal of Learning \& Development, 4(1), 7182.

Syah, M. (2012). Psikologi Belajar Cet. Ke-12. Jakarta: RajaGrafindo Persada.

Tao, S., Lu, S., Geng, Y., Zhu, S., Redfern, S. A., Song, Y., Feng, T., Xu, W., \& Yang, B. (2018). Design of metal-free polymer carbon dots: A new class of roomtemperature phosphorescent materials. Angewandte Chemie International Edition, 57(9), 2393-2398.

Tomba, E., Belaise, C., Ottolini, F., Ruini, C., Bravi, A., Albieri, E., Rafanelli, C., Caffo, E., \& Fava, G. A. (2010). 
Differential effects of well-being promoting and anxiety-management strategies in a non-clinical school setting. Journal of Anxiety Disorders, 24(3), 326-333.

Wardle, J., \& Cooke, L. (2005). The impact of obesity on psychological well-being. Best Practice \& Research Clinical Endocrinology \& Metabolism, 19(3), 421-440.
White, M. A., \& Waters, L. E. (2015). A case study of 'The Good School:'Examples of the use of Peterson's strengths-based approach with students. The Journal of Positive Psychology, 10(1), 69-76.

Wright, T. A., \& Cropanzano, R. (2000). Psychological well-being and job satisfaction as predictors of job performance. Journal of Occupational Health Psychology, 5(1), 84. 